\title{
ARHGAP5 wt Allele
}

National Cancer Institute

\section{Source}

National Cancer Institute. ARHGAP5 wt Allele. NCI Thesaurus. Code C97280.

Human ARHGAP5 wild-type allele is located in the vicinity of $14 q 12$ and is approximately $82 \mathrm{~kb}$ in length. This allele, which encodes Rho GT Pase-activating protein 5, plays a role in the modulation of GT Pase activity. 